\title{
Differential response of immune-related genes to peptidoglycan and lipoteichoic acid challenge in vitro
}

\author{
Sourabh Sulabh, Bharat Bhushan, Manjit Panigrahi, Ankita Verma, Naseer Ahmad Baba and Pushpendra Kumar \\ Division of Animal Genetics, ICAR-Indian Veterinary Research Institute, Izatnagar, Bareilly - 243122 , \\ Uttar Pradesh, India. \\ Corresponding author: Bharat Bhushan, e-mail: bhushan.drbharat@gmail.com, \\ SS: sourabhjsr.vtro4@gmail.com, MP: manjit707@gmail.com, AV: ankita.d_verma@yahoo.co.in, \\ NAB: naseervet@gmail.com, PK: pushpendra64@gmail.com \\ Received: 05-05-2016, Accepted: 01-08-2016, Published online: 17-09-2016
}

doi: 10.14202/vetworld.2016.983-988 How to cite this article: Sulabh S, Bhushan B, Panigrahi M, Verma A, Baba NA, Kumar P (2016) Differential response of immune-related genes to peptidoglycan and lipoteichoic acid challenge in vitro, Veterinary World, 9(9): 983-988.

\begin{abstract}
Aim: To study the effect of Staphylococcus aureus cell wall antigens, peptidoglycan (PGN) and lipoteichoic acid (LTA) challenge on immune cells present in bovine peripheral blood mononuclear cells (PBMCs).

Materials and Methods: In this study, efforts have been made to investigate the effects of three combinations $(10+10$, $20+20$ and $30+30 \mu \mathrm{g} / \mathrm{ml}$ ) of PGN and LTA obtained from $S$. aureus. These antigens were used to challenge the bovine PBMCs. After $6 \mathrm{~h}$ of incubation quantitative, real time-polymerase chain reaction was used to study toll-like receptor 2 (TLR-2) and major cytokine mRNA expression in bovine PBMC challenged with three different antigen blends.

Results: The results indicated that mRNA level of interferon gamma is influenced by the expression of TLR-2 gene. Tumor necrosis factor-alpha (TNF- $\alpha$ ), interleukin 10 (IL-10), and IL-8 genes showed a maximum response at a dose of $10 \mu \mathrm{g}$ of PGN and $10 \mu \mathrm{g}$ of LTA challenge per $\mathrm{ml}$ of culture medium. The outcome also suggests that both IL-10 and IL-8 followed the expression pattern of TNF- $\alpha$.
\end{abstract}

Conclusion: A dose of $10 \mu \mathrm{g}$ of PGN and $10 \mu \mathrm{g}$ of LTA per ml of culture medium was found to be most suitable for challenging PBMC.

Keywords: expression, lipoteichoic acid, mastitis, peptidoglycan, peripheral blood mononuclear cell.

\section{Introduction}

Inflammation of the mammary gland and udder tissue is known as mastitis. The most pertinent cause of mastitis is the immune response that occurs due to the various bacterial sources invading the teat canal. The losses due to mastitis have been estimated to the tune of about 2 billion dollars in the USA and 526 million dollars in India [1]. Its prevalence is common even in very well-managed dairy farms. Bovine mastitis is most commonly caused by Staphylococcus aureus, Streptococcus uberis, and Escherichia coli [2]. Mastitis due to S. aureus infection is known to generally cause sub-clinical form of the infection which has a tendency to show resistance against antibiotic therapy [3]. Peptidoglycan (PGN) and lipoteichoic acid (LTA) present in the cell wall of Gram-positive bacteria, one of which is $S$. aureus have been recognized as a potent antigen having ability to stimulate the immune system of the host [4]. PGN and LTA act as pathogen-associated molecular patterns for pattern recognition receptors (PRRs)

Copyright: Sulabh, et al. Open Access. This article is distributed under the terms of the Creative Commons Attribution 4.0 International License (http://creativecommons.org/licenses/ by/4.0/), which permits unrestricted use, distribution, and reproduction in any medium, provided you give appropriate credit to the original author(s) and the source, provide a link to the Creative Commons license, and indicate if changes were made. The Creative Commons Public Domain Dedication waiver (http:// creativecommons.org/publicdomain/zero/1.0/) applies to the data made available in this article, unless otherwise stated. such as membrane protein and toll-like receptor 2 (TLR-2) [5]. Lymphocytes, monocytes, and macrophages serve as the effective regulators of inflammation and serve as the foremost line of the immune system against the invading microbes [6]. These cells have the capability to produce inflammatory conciliator such as cytokines and chemokines, which act by engaging other immune cells to the site of inflammation. Lymphocytes are present in the mammary gland secretions and play an important role in providing protection against mastitis causing organisms [7]. Various studies have recognized that the composition of the T-lymphocyte subpopulation showed susceptibility or resistance to intramammary infection [8]. Monocytes are known to produce a high amount of potent proinflammatory mediators. Macrophages are directly involved in phagocytosis of foreign bodies and also act as an important antigen presenting cell [9]. Their local recruitment and activity provide protection to the mammary gland from invading pathogens [10].

Although $S$. aureus vaccine development has not been successful either in humans or in animals, further insight and study of cytokine expression pattern may help in finding an appropriate solution. Evidence of the use of $S$. aureus ghost vaccine having only the outer envelope of the cell (containing PGN, LTA, and proteins) and also a separate experiment of injecting only PGN was found to induce protective immunity to a lethal challenge in experimental animals $[11,12]$. 
In this study, an attempt has been made to investigate the differential expression of genes in peripheral blood mononuclear cells (PBMCs) from crossbred cattle challenged with different doses of $S$. aureus antigens like PGN and LTA.

\section{Materials and Methods}

\section{Ethical approval}

Collection of blood required for the study was approved by the Institutional Animal Ethics Committee.

\section{Selection of animals and blood collection}

Healthy crossbred cattle $(50-75 \%$ inheritance from cattle breeds involving Holstein-Friesian, Jersey, and Brown Swiss with the native indigenous component stabilized in between $25 \%$ and $50 \%$ from Hariana cattle breed) maintained at cattle and buffalo farm, ICAR-Indian Veterinary Research Institute Izatnagar, in their $3^{\text {rd }}$ and $4^{\text {th }}$ parities were screened on the basis of the records of mastitis occurrence. Only those animals that were never affected by mastitis were selected for the study. To rule out the probability of sub-clinical mastitis, they were then examined for milk somatic cell count (SCC) and California mastitis test (CMT) score. Animals having SCC below 200,000 and showing CMT score of 0 and 1 were selected for collection of blood samples. Blood was collected from four animals. PBMC was isolated from blood at room temperature by density gradient centrifugation (Histopaque - $1.083 \mathrm{~g} / \mathrm{ml}$, Sigma, Poole, Dorset, UK). The isolated cells were suspended in red blood cell (RBC) lysis buffer so that lysis of any RBCs left during the separation procedure could be completed. Roswell Park Memorial Institute-1640 media, supplemented with $10 \%$ fetal calf serum, $0.1 \mathrm{mg} / \mathrm{ml}$ ampicillin, $0.1 \mathrm{mg} / \mathrm{ml}$ of kanamycin, $0.001 \mathrm{mg} / \mathrm{ml}$ amphotericin B, was then used to wash the isolated mononuclear cells by first mixing with the media and then centrifuging it at $200 \mathrm{~g}$ for $10 \mathrm{~min}$ each. Each time supernatant separated by centrifugation was thrown, and the pellet was kept for further processing. The recovery and viability of the isolated PBMC were determined by Countess ${ }^{\mathrm{TM}}$ Automated Cell Counter (Invitrogen, USA). $10 \mu 1$ of $0.4 \%$ trypan blue was pipetted and mixed with $10 \mu \mathrm{l}$ of cell suspension, which was incubated for 3 min at room temperature. Out of this mixture, $10 \mu \mathrm{l}$ was then loaded in the chamber of Countess ${ }^{\circledR}$ Cell Counting Slides (Invitrogen, USA). The slides were then inserted into the slide port of the countess, and the reading was taken. The total number of viable cells counted on an average was $1 \times 10^{6} / \mathrm{ml}$, accounting for more than $85 \%$ viability. Cells from each animal were then divided into four wells and were plated at a density of $1 \times 10^{6}$ cells $/ \mathrm{ml}$. The PBMC was then challenged with PGN+LTA obtained from $S$. aureus cell wall (SigmaAldrich, Saint Louis, USA) at a dose rate of $10+10$, $20+20$ and $30+30 \mu \mathrm{g} / \mathrm{ml}$ of culture media for a total of $6 \mathrm{~h}$ in 6 well plates $\left(3 \times 10^{6}\right.$ cells $/$ well $)$ at $37^{\circ} \mathrm{C}$ with
$5 \% \mathrm{CO}_{2}$. A non-challenged PBMC was kept as a control which was also maintained at $37^{\circ} \mathrm{C}$ with $5 \% \mathrm{CO}_{2}$. The above process was again repeated on the $2^{\text {nd }}$ day for the same set of animals and the PBMC of the same animals and conditions (challenged and non-challenged) obtained by centrifugation after the final step of incubation was pooled together.

\section{Bovine PBMC challenge with PGN and LTA}

The dose rate for challenge of bovine PBMC was decided on the basis of previously described protocols involving in vitro stimulation of bovine mammary epithelial cells or bovine PBMC by either LTA or PGN or a combination of both [13-15]. The time period of $6 \mathrm{~h}$ was considered because most of the inflammatory cytokines after reaching an expression peak at about 4-6 h were either found to have no change or showed a decrease in the level of cytokines even after 12 or $24 \mathrm{~h}$ of challenge [13].

Total RNA extraction and quantitative real time-polymerase chain reaction ( $\mathrm{QRT}$-PCR) analysis

The procedure for RNA isolation was followed using RNeasy Plus Mini Kit (Qiagen) as per the manufacturer's instructions. RNA Quantification was done by NanoDrop ND 1000 Spectrophotometer (Thermo Scientific, Wilmington, DE, USA). First strand cDNA synthesis was done using High-Capacity RNA-tocDNA $^{\mathrm{TM}}$ Kit (Applied Biosystems, USA) following the manufacturer's instructions under the following conditions: $37^{\circ} \mathrm{C}$ for $60 \mathrm{~min}$ followed by $95^{\circ} \mathrm{C}$ for 5 min and subsequent hold at $4^{\circ} \mathrm{C}$. Taking efficiency of cDNA synthesis as $100 \%$, it was diluted to a final concentration of $5 \mathrm{ng} / \mu \mathrm{l}$. Real-time PCR reactions were performed using Fast $\mathrm{SYBR}^{\circledR}$ Green Master mix (Applied Biosystems, Warrington, UK). The thermal cycling program of the qPCR included one cycle at $95^{\circ} \mathrm{C}$ for $10 \mathrm{~min}$ followed by 40 cycles at $95^{\circ} \mathrm{C}$ for $15 \mathrm{~s}$ and $60^{\circ} \mathrm{C}$ for $1 \mathrm{~min}$. A dissociation step was also included to confirm the specificity of amplification. Four biological samples and three technical replicates of each sample were used in this study. Comparative $\mathrm{C}_{\mathrm{T}}$ method [16] was used to analyze the generated data.

The production of the melt curve as a result of the dissociation was observed for the presence of a single peak, which represented a single PCR product for each gene amplified. A negative template control was included in the RT-PCR reaction where instead of cDNA nuclease free water was added to the reaction mixture. For all sets of primers, reaction efficiencies were calculated using a two-fold serial dilution of pooled cDNA. A standard curve was constructed by plotting average CTs against $\log _{10}$ (cDNA concentration/100). The line obtained from the slope (m) was used to calculate the efficiencies of primers using the formula $10^{(-1 / \mathrm{m})-1}$. Primers with efficiencies between 0.8 and 1.1 were considered acceptable and were included in the study (Table-1). Expression of $\beta$-actin was the most stable across all sample types 
Table-1: Sequences of oligonucleotide primers\#.

\begin{tabular}{|c|c|c|c|c|}
\hline Gene name & Primer sequence $\left(5^{\prime}-3^{\prime}\right)$ & $\begin{array}{l}\text { Amplicon } \\
\text { size (bp) }\end{array}$ & $\begin{array}{l}\text { Accession } \\
\text { number }\end{array}$ & References \\
\hline IL-10 & $\begin{array}{l}\text { F: CTTGTCGGAAATGATCCAGT } \\
\text { R: TCTCTTGGAGCTCACTGAAG }\end{array}$ & 208 & NM_174088 & Strandberg et al., 2005 \\
\hline IFNG & $\begin{array}{l}\text { F: GTGGGCCTCTCTTCTCAGAA } \\
\text { R: GATCATCCACCGGAATTTGA }\end{array}$ & 234 & M29867 & Strandberg et al., 2005 \\
\hline TNF-a & $\begin{array}{l}\text { F: CTGGTTCAGACACTCAGGTCCT } \\
\text { R: GAGGTAAAGCCCGTCAGCA }\end{array}$ & 183 & AF011926 & Strandberg et al., 2005 \\
\hline TLR-2 & $\begin{array}{l}\text { F: AGCACTTCAACCCTCCCTTT } \\
\text { R: GAATCAGAATGGCAGCATCA }\end{array}$ & 216 & NM_174197 & Strandberg et al., 2005 \\
\hline IL-8 & $\begin{array}{l}\text { F: CACTGTGAAAATTCAGAAATCATTGTTA } \\
\text { R: CTTCACAAATACCTGCACAACCTT }\end{array}$ & 103 & S82598.1 & \\
\hline GAPDH & $\begin{array}{l}\text { F: TGACCCCTTCATTGACCTTC } \\
\text { R: GATCTCGCTCCTGGAAGATG }\end{array}$ & 143 & BC102589.1 & \\
\hline HPRT & $\begin{array}{l}\text { F: GTGGGATATGCCCTTGACTATAA } \\
\text { R: GTGGGATATGCCCTTGACTATAA }\end{array}$ & 104 & NM_001034035.2 & \\
\hline$\beta$-actin & $\begin{array}{l}\text { F: CATCGGCAATGAGCGGTTC } \\
\text { R: ACAGCACCGTGTTGGCGTAG }\end{array}$ & 146 & BC142413.1 & \\
\hline
\end{tabular}

\#Primers for IL-8, GAPDH, HPRT and $\beta$-actin were designed using integrated DNA technologies online software PrimerQuest Tool and were verified by OligoAnalyzer Tool (Coralville, Iowa, U.S.A). IL-8=Interleukin 8, $\mathrm{GAPDH}=$ Glyceraldehyde-3-phosphate dehydrogenase, HPRT=Hypoxanthine phosphoribosyltransferase, TLR-2=Toll like receptor 2, TNF- $a=$ Tumor necrosis factor-alpha, IFNG=Interferon gamma

( $\mathrm{M}$ value $=0.55)$. $\beta$-actin was therefore selected as a reference gene for normalization of expression data. $\log _{2}$ fold change conversion was made to the qRTPCR data relative to control untreated samples using the $2^{-\Delta \Delta \mathrm{CT}}$ method.

\section{Results}

Cytokine mRNA expression of bovine PBMC against PGN+LTA challenge

The effect of $S$. aureus cell wall antigens $(\mathrm{PGN}+\mathrm{LTA})$ at a dose rate of $10+10,20+20$, $30+30 \mu \mathrm{g} / \mathrm{ml}$ on bovine PBMC cytokine mRNA expression was determined in culture after $6 \mathrm{~h}$ of incubation. A control was also kept (bovine PBMC without any antigen) for $6 \mathrm{~h}$ of incubation for comparing the cytokine profiles of challenged samples. The result showed significant up-regulation of both TLR-2 and interferon gamma (IFNG) at all the doses of PGN and LTA combinations. The expression of TLR-2 gene showed a gradual increase in mRNA expression $(p<0.001)$ with increase in the dose of the antigens $20+20 \mu \mathrm{g} / \mathrm{ml}$ followed by decrease with further increase in the concentration of the antigen blend $30+30 \mu \mathrm{g} / \mathrm{ml}$, which has been shown in Figure-1. Similar fold change expression was also shown by IFNG, but the pattern was much steeper than that of TLR-2 mRNA expression profile. A significant up-regulation of IFNG $(\mathrm{p}<0.01)$ was observed at $10+10$ and $30+30 \mu \mathrm{g} / \mathrm{ml}$ of $S$. aureus antigens (Figure-2). The up-regulation of IFNG was much more at $20+20 \mu \mathrm{g} /$ $\mathrm{ml}$ antigen challenge $(\mathrm{p}<0.001)$.

Interleukin 10 (IL-10) (Figure-3) and IL-8 (Figure-4) showed a significant up-regulation $(\mathrm{p}<0.001)$ when PBMC was incubated with $10 \mu \mathrm{g}$ PGN with $10 \mu \mathrm{g}$ LTA per ml of culture media. But as the dose was further increased to $20+20 \mu \mathrm{g}$ and then to $30+30 \mu \mathrm{g}$ antigen challenge per $\mathrm{ml}$ of culture down-regulation in the expression of the genes

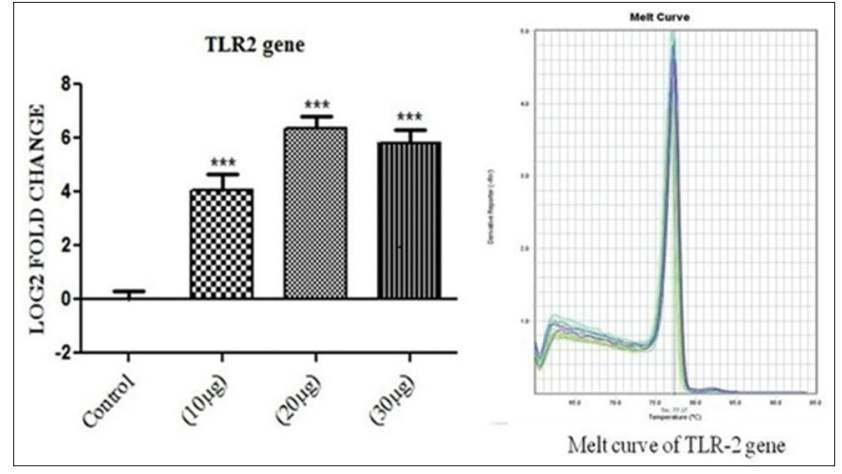

Figure-1: The figure depicts 4.06, 6.36 and $5.83 \log _{2}$ fold highly significant difference of toll like receptor 2 mRNA expression $\mathrm{n}=4$ in $10+10 \mu \mathrm{g}, 20+20 \mu \mathrm{g}$ and $30+30 \mu \mathrm{g}$ peptidoglycan + lipoteichoic acid per $\mathrm{ml}$ of peripheral blood mononuclear cell challenged groups, respectively, as compared to control. Data are normalized to the reference gene. The one-way ANOVA with Newman-Keuls multiple comparison test was performed to determine the significant differences between $\Delta C T s$ of the analyzed groups.

were observed at $\mathrm{p}<0.01$ and $\mathrm{p}<0.001$, respectively. Tumor necrosis factor-alpha $(\mathrm{TNF}-\alpha)$ showed significant up-regulation of the expression at $10+10 \mu \mathrm{g}$ of PGN+LTA challenge $(\mathrm{p}<0.001)$ but its expression became non-significant when the amount was increased to $20+20 \mu \mathrm{g}$ of antigens per ml of media as shown in Figure-5. Moreover, TNF- $\alpha$ showed non-significant down-regulation with an increase in the quantity of antigen challenge $(30 \mu \mathrm{g}$ PGN $+30 \mu \mathrm{g}$ LTA per ml of culture media).

\section{Discussion}

Cattle with the higher response of cell-mediated immune response (CMIR) or antibody mediated immune response (AMIR) have lower incidence of mastitis in comparison to low or average responders [17-19]. Both CMIR and AMIR responses are produced by blood mononuclear cells. TLR signaling as 


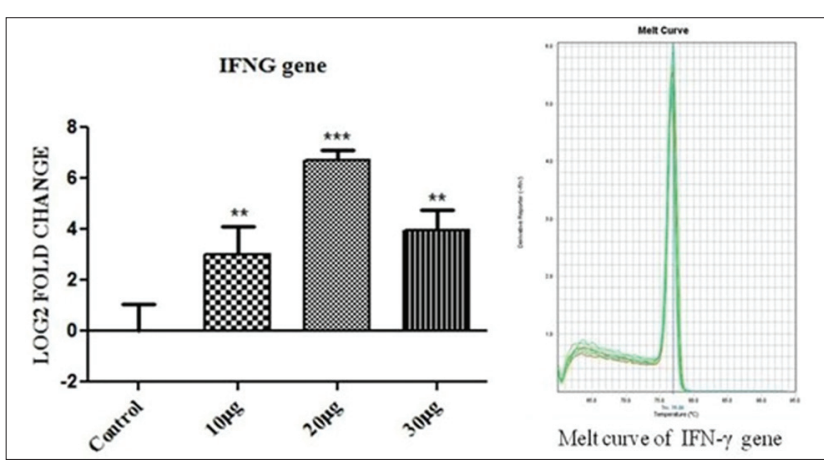

Figure-2: The figure depicts $3.03,6.72$ and $3.97 \log$ fold significant up-regulation of interferon gamma mRNA expression $\mathrm{n}=4$ in $10+10 \mu \mathrm{g}, 20+20 \mu \mathrm{g}$ and $30+30 \mu \mathrm{g}$ peptidoglycan + lipoteichoic acid per $\mathrm{ml}$ of peripheral blood mononuclear cell challenged groups respectively, as compared to control. Data are normalized to the reference gene. The one-way ANOVA with Newman-Keuls multiple comparison test was performed to determine the significant differences between $\Delta C T$ s of the analyzed groups.

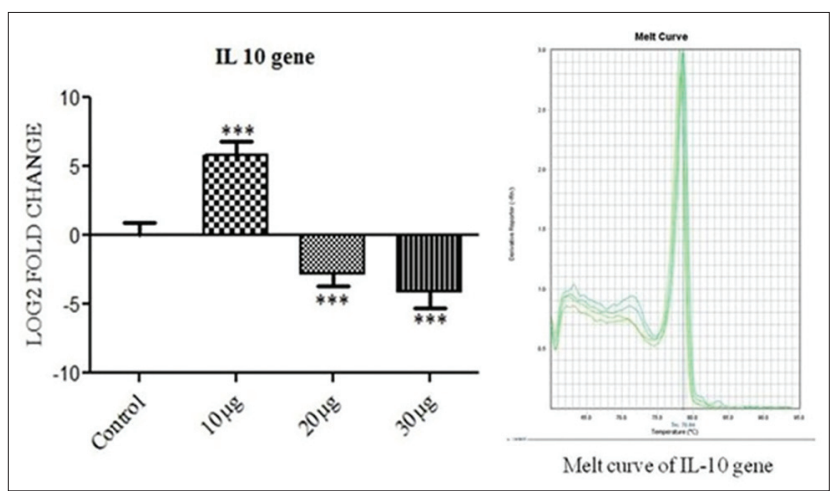

Figure-3: The figure depicts $5.77,-2.74$ and $-4.12 \log _{2}$ fold significant difference of interleukin 10 mRNA expression $\mathrm{n}=4$ in $10+10 \mu \mathrm{g}, 20+20 \mu \mathrm{g}$ and $30+30 \mu \mathrm{g}$ peptidoglycan + lipoteichoic acid per $\mathrm{ml}$ of peripheral blood mononuclear cell challenged groups, respectively, as compared to control. Data are normalized to the reference gene. The one-way ANOVA with Newman-Keuls multiple comparison test was performed to determine the significant differences between $\Delta C T s$ of the analyzed groups.

well as cytokines, influence macrophages and dendritic cells to act as antigen presenting cells and thus, activate T-helper (Th) cell sub-populations. Th1 cells predominately produce cytokines that generate a CMIR in response to intracellular microbes [20]. In contrast, Th2 cells fabricate those cytokines that tend to generate an AMIR toward extracellular pathogens such as E. coli which is known to cause mastitis [20]. TNF$\alpha$, IFNG, and IL-8 release favors Th1 type response whereas IL-10 is biased toward Th2 type response of immune cells [21]. Th1 type response is specific and is of main importance for the development of modern vaccines. There is increase in the level of Th1 and Th2 type cells in mammary gland mediated by proinflammatory cytokines when infected by $S$. aureus causing mastitis; the release of proinflammatory cytokines is tightly regulated by the production of IL-10 cytokine [22]. In the United States, J5 vaccine for protection of mastitis against $E$. coli has been used successfully, which has been explained on

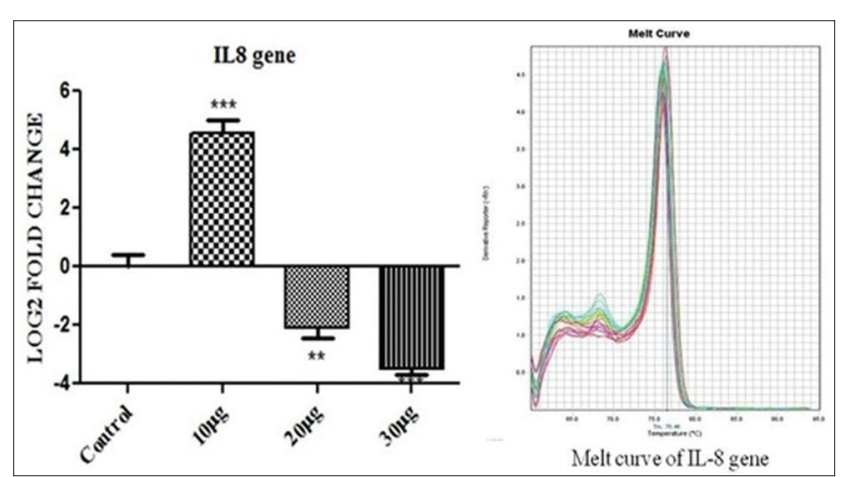

Figure-4: The figure depicts $4.56,-2.1$ and $-3.49 \log _{2}$ fold significant difference of interleukin 10 mRNA expression $\mathrm{n}=4$ in $10+10 \mu \mathrm{g}, 20+20 \mu \mathrm{g}$, and $30+30 \mu$ g peptidoglycan + lipoteichoic acid per $\mathrm{ml}$ of peripheral blood mononuclear cell challenged groups respectively, as compared to control. Data are normalized to the reference gene. The one-way ANOVA with Newman-Keuls multiple comparison test was performed to determine the significant differences between $\Delta \mathrm{CTs}$ of the analyzed groups.

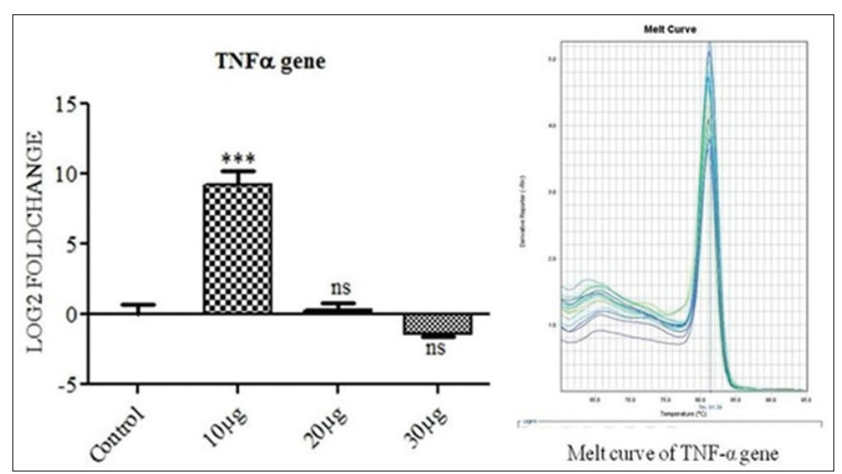

Figure-5: The figure depicts $9.22,0.36$ and $-1.37 \log _{2}$ fold difference of tumor necrosis factor-alpha mRNA expression $\mathrm{n}=4$ in $10+10 \mu \mathrm{g}, 20+20 \mu \mathrm{g}$ and $30+30 \mu \mathrm{g}$ peptidoglycan + lipoteichoic acid per $\mathrm{ml}$ of peripheral blood mononuclear cell challenged groups respectively, as compared to control. Data are normalized to the reference gene. The one-way ANOVA with Newman-Keuls multiple comparison test was performed to determine the significant differences between $\Delta C T s$ of the analyzed groups.

the mechanism of increased antibody production and greater opsonization of lipopolysaccharides and the coliform bacteria [23].

At the site of infection, TNF- $\alpha$ promotes activation of cells and recruitment of leukocytes. TNF- $\alpha$ is also produced by monocytes, macrophages, and lymphocytes [24]. Sources of IFNG, IL-8, and IL-10 genes include lymphocytes and cells of monocytic lineages [25]. IFNG forms an integral component of the innate immune system and acts by enhancing the phagocytic activities of monocytes and macrophages. Increase in IL-8 activity is followed by recruitment of neutrophils and to lesser extent T-lymphocytes [26]. IL-10 as an anti-inflammatory cytokine is involved in the regulatory activity of pro-inflammatory cytokines [27].

The results demonstrate that TLR-2 acts as an important PRR which also affects or control the signaling of other important cytokines. Gram-positive bacteria cell wall components such as PGN and 
LTA activates immune cells, which is mediated by TLR-2 [28]. TLR-2 agonists PGN and LTA enhances IFNG release specific to the antigen in whole blood [5]. We demonstrated that PGN and LTA were able to induce similar responses in both TLR-2 and IFNG. With the increase in the dose of antigens, expression of both TLR-2 and IFNG elevated but followed by a decrease with more increase in the dosage of the antigens. This pattern gives an indication that the level of IFNG is influenced by the expression of TLR-2 gene. IFNG has been reported as an important feature of innate and adaptive immunity and is specified by the quick response and increased production against an infection [27]. The results of this study showed significant up-regulation of TNF- $\alpha$ at low doses of antigen stimulation of cattle PBMC which was similar to those found during in vitro study using either live or dead bacteria [28]. TNF- $\alpha$ stimulates endothelial activation and recruitment of leukocytes to the site of infection [29]. Besides, TNF- $\alpha$ was also proposed as one of the potential DNA markers in the improvement of immunity to mastitis [30].

IL-8 and IL-10 also showed significant up-regulation at low dose challenge which shifted towards down-regulation on stimulation of PBMC with higher doses. IL-8 gene was found to be up-regulated in blood mononuclear cells during mastitis caused by $S$. aureus [31]. Our results showed an increase in the quantity of IL- 8 mRNA with rise in the level of TNF- $\alpha$. However, the expression was down-regulated or decreased as the amount of cell wall antigen challenge was increased. IFNG, TNF- $\alpha$, and IL- 8 act as pro-inflammatory cytokine, whereas IL-10 act as anti-inflammatory cytokine. Anti-inflammatory effect on monocytes, macrophages and neutrophils is exerted by IL- 10 by decreasing the production of chemokines, cytokines and eicosanoids involved in proinflammatory reactions [32]. IL-10 being an anti-inflammatory cytokine; its main function is to control the excessive release of certain pro-inflammatory cytokines like TNF- $\alpha$ [24]. The result indicates that IL-10 is involved in the regulatory mechanism of TNF- $\alpha$ release from immune cells present in PBMC which helps in the avoidance of TNF- $\alpha$ mediated septic shock. IL-10 being the most important anti-inflammatory cytokine also suppresses the expression of IFNG to shift the Th1 type response to Th2 type response [32]. But, as the dose of the antigens was increased in our study, the level of IL-10 did not increase to counter the effect of increase in IFNG expression. The result strongly suggests that the expression of IL-10 followed the expression of TNF- $\alpha$ and was not influenced by the expression pattern of IFNG. The overall decrease in the expression of genes at higher concentrations of antigen challenge in the current study might be due to cellular apoptosis induced by TLR-2.

The study indicates the potential of cell wall antigens of $S$. aureus to be used for the production of vaccines as these antigens are also able to activate immune responses in cell cultures. The study is also beneficial for in vitro challenge and comparison of innate immune response of different breeds of animals, as well as a comparison between different species, which may help in generating data giving an indication about the difference in the pattern and regularity of mastitis infection between different breeds and species of animal.

\section{Conclusion}

It can be said that a dose of $10 \mu \mathrm{g}$ of PGN and $10 \mu \mathrm{g}$ of LTA per ml of culture medium was found to be most suitable for challenging PBMC. The mRNA expression of genes taken under study showed similarity to studies in which cells were challenged either by live or killed $S$. aureus. The research revealed about the involvement of TLR-2 activity as a major PRR with coordinated activities of cytokines involved in Th1 and Th2 types of immune response.

\section{Authors' Contributions}

BB, MP, PK and SS: Planning of the research and analysis of the result. SS, AV and NAB: Carried out all the research work (culture, challenge. RNA isolation, cDNA synthesis, qRT-PCR reactions, arranging data in excel). All authors participated in draft and revision and approved the final manuscript.

\section{Acknowledgments}

The authors wish to acknowledge the funds and assistance rendered by Director, Indian Veterinary Research Institute, Izatnagar, Bareilly, India, for providing necessary facilities to carry out this work.

\section{Competing Interests}

The authors declare that they have no competing interests.

\section{References}

1. Varshney, J.P. and Naresh, R. (2004) Evaluation of homeopathic complex in the clinical management of udder diseases of riverine buffaloes. Homeopathy, 93(1): 17-20.

2. Watts, J.L. (1988) Etiological agents of bovine mastitis. Vet. Microbiol., 16: 41-66.

3. Von Eiff, C., Peters, G. and Becker, K. (2006) The small-colony variant (SCV) concept - The role of Staphylococcus SCVs in persistent infections. Injury, 37(2): S26-S33.

4. Tilahun, A.Y., Karau, M., Ballard, A., Gunaratna, M.P., Thapa, A., David, C.S., Patel, R. and Rajagopalan, G. (2014) The impact of Staphylococcus aureus - associated molecular patterns on staphylococcal superantigen-induced toxic shock syndrome and pneumonia. Mediators Inflamm., 2014: 468285 .

5. Dammermann, W., Wollenberg, L., Bentzien, F., Lohse, A. and Lüth, S. (2013) Toll like receptor 2 agonists lipoteichoic acid and PGN are able to enhance antigen specific IFN gamma release in whole blood during recall antigen responses. J. Immunol. Methods, 396(1-2): 107-115.

6. Mogensen, T.H. (2009) Pathogen recognition and inflammatory signaling in innate immune defenses. Clin. Microbiol. Rev., 22(2): 240-273.

7. Park, Y.H., Joo, Y.S., Park, J.Y., Moon, J.S., Kim, S.H., Kwon, N.H., Ahn, J.S., Davis, W.C. and Davies, C.J. (2004) Characterization of lymphocyte subpopulations and major 
histocompatibility complex haplotypes of mastitis-resistant and susceptible cows. J. Vet. Sci., 5(1): 29-39.

8. Taylor, B.C., Dellinger, J.D., Cullor, J.S. and Stott, J.L. (1994) Bovine milk lymphocytes display the phenotype of memory $\mathrm{T}$ cells and are predominantly $\mathrm{CD} 8+$. Cell Immunol., 156: 245-253.

9. Alnakip, M.E., Quintela-Baluja, M., Böhme, K., Fernández-No, I., Caamaño-Antelo, S., Calo-Mata, P. and Barros-Velázquez, J. (2014) The immunology of mammary gland of dairy ruminants between healthy and inflammatory conditions. J. Vet. Med., 2014: 1.

10. Lewandowska-Sabat, A.M., Boman, G.M., Downing, A., Talbot, R., Storset, A.K. and Olsaker, I. (2013) The early phase transcriptome of bovine monocyte-derived macrophages infected with Staphylococcus aureus in vitro. BMC Genomics, 14: 891.

11. Vinod, N., Oh, S., Park, H.J., Koo, J.M., Choi, C.W. and Kim, S.C. (2015) Generation of a novel Staphylococcus aureus ghost vaccine and examination of its immunogenicity against virulent challenge in rats. Infect. Immun., 83(7): 2957-2965.

12. Capparelli, R., Nocerino, N., Medaglia, C., Blaiotta, G., Bonelli, P. and Iannelli, D. (2011) The Staphylococcus aureus peptidoglycan protects mice against the pathogen and eradicates experimentally induced infection. PLoS One, 6(12): Article No: e28377.

13. Strandberg, Y., Gray, C., Vuocolo, T., Donaldson, L., Broadway, M. and Tellam, R. (2005) Lipopolysaccharide and lipoteichoic acid induce different innate immune responses in bovine mammary epithelial cells. Cytokine, 31: 72-86.

14. Mount, J.A., Karrow, N.A., Caswell, J.L., Boermans, H.J. and Leslie, K.E. (2009) Assessment of bovine mammary chemokine gene expression in response to lipopolysaccharide, lipotechoic acid + peptidoglycan, and $\mathrm{CpG}$ oligodeoxynucleotide 2135. Can. J. Vet. Res., 73: 49-57.

15. Shah, S.M., Kumar, G.V.P., Brah, G.S., Santra, L. and Pawar, H. (2012) differential expression of Th1- and Th2- type cytokines murrah buffalo (Bubalus bubalis) on TLR2 induction by B. Subtilis peptidoglycan. Asian Aust. J. Anim., 25(7): 1021-1028.

16. Schmittgen, T.D. and Livak, K.J. (2008) Analyzing realtime PCR data by the comparative CT method. Nat. Protoc., 3: 1101-1108.

17. Wagter, L.C., Mallard, B.A., Wilkie, B.N., Leslie, E.K., Boettcher, P.J. and Dekkers, K.E. (2000) A quantitative approach to classifying Holstein cows based on antibody responsiveness and its relationship to peripartum mastitis occurrence. J. Dairy Sci., 83: 488-498.

18. Thompson-Crispi, K.A., Hine, B., Quinton, M., Miglior, F. and Mallard, B.A. (2012) Short communication: Association of disease incidence and adaptive immune response in Holstein dairy cows. J. Dairy Sci., 95: 3888-3893.

19. Thompson-Crispi, K.A., Miglior, F. and Mallard, B.A. (2013) Incidence rates of clinical mastitis among Canadian
Holsteins classified as high, average and low immune responders. Clin. Vaccine Immunol., 20: 106-112.

20. Wagter-Lesperance, L., Hodgins, D., Emam, S., Paibomesai, M. and Mallard, B. (2014) Expression of TLR2 pattern recognition receptor on mononuclear cells of dairy cattle ranked using estimated breeding values (EBV) of adaptive immune response traits. Proceedings, $10^{\text {th }}$ World Congress on Genetics Applied to Livestock Production, August 17 - 22, 2014; Vancouver, BC Canada. p548.

21. Babu, S. and Nutman, T.B. (2003) Proinflammatory cytokines dominate the early immune response to filarial parasites. J. Immunol., 171: 6723-6732.

22. Zhao, Y., Zhou, M., Gao, Y., Liu, H., Yang, W., Yue, J. and Chen, D. (2015) Shifted T helper cell polarization in a murine Staphylococcus aureus mastitis model. PLoS One, 10(7): $\mathrm{e} 0134797$

23. Dosogne, H., Vangroenweghe, F. and Burvenich, C. (2002) Potential mechanism of action of $\mathrm{J} 5$ vaccine in protection against severe bovine coliform mastitis. Vet. Res., 33: 1-12.

24. Bannerman, D.D. (2009) Pathogen-dependent induction of cytokines and other soluble inflammatory mediators during intramammary infection of dairy cows. J. Anim. Sci., 87(1): 10-25.

25. Kobayashi, Y. (2008) The role of chemokines in neutrophil biology. Front. Biosci., 13: 2400-7.

26. Schwandner, R., Dziarski, R., Wesche, H., Rothe, M. and Kirschning, C.J. (1999) PGN- and lipoteichoic acid-induced cell activation is mediated by toll-like receptor 2 . J. Biol. Chem., 274: 17406-17409.

27. Muhl, H. and Pfeilschifter, J. (2003) Anti-inflammatory properties of pro-inflammatory interferon-gamma. Int. Immunopharmacol., 3: 1247-55.

28. Gondaira, S., Higuchi, H., Iwano, H., Nakajima, K., Kawai, K., Hashiguchi, S., Konnai, S. and Nagahata, H. (2015) Cytokine mRNA profiling and the proliferative response of bovine peripheral blood mononuclear cells to Mycoplasma bovis. Vet. Immunol. Immunop., 165(1-2): 45-53.

29. Oviedo-Boyso, J., Cardoso-Correa, B.I., Cajero-Juárez, M., Bravo-Patiño, A., Valdez-Alarcón, J.J. and BaizabalAguirre, V.M. (2008) The capacity of bovine endothelial cells to eliminate intracellular Staphylococcus aureus and Staphylococcus epidermidis is increased by the proinflammatory cytokines TNF- $\alpha$ and IL-1 $\beta$. FEMS Immunol. Med. Microbiol., 54: 53-59.

30. Wojdak-Maksymiec, K., Szyda, J. and Strabel, T. (2013) Parity-dependent association between TNF- $\alpha$ and LTF gene polymorphisms and clinical mastitis in dairy cattle. $B M C$ Vet. Res., 9: 114.

31. Tao, W. and Mallard, B. (2007) Differentially expressed genes associated with Staphylococcus aureus mastitis of Canadian Holstein cows. Vet. Immunol. Immunop., 44: 201-211

32. Moore, K.W., Malefyt, R.W., Coffman, R.L. and O'Garra, A. (2001) Interleukin-10 and the interleukin-10 receptor. Annu. Rev. Immunol., 19: 683-765. 